Науковий вісник НЛТУ України Scientific Bulletin of UNFU https://nv.nltu.edu.ua https://doi.org/10.36930/40300110

Article received 19.02.2020 p.

Article accepted 27.02.2020 p.
ISSN 1994-7836 (print)

ISSN 2519-2477 (online)

$@ \bowtie$ Correspondence author

Ya. V. Henyk

yarhenyk@gmail.com

UDK 580.066.01(477.72)

Н. Я. Мельничук, Я. В. Геник, С. П. Мельничук, М. М. Паславський

Національний лісотехнічний університет Украйни, м. Львів, Украӥна

\title{
ПРИРОДНІ ПРОЦЕСИ РОЗВИТКУ ТА ВЗАЕМОВІДНОСИНИ КОМПОНЕНТІВ САДОВО-ПАРКОВИХ ЕКОСИСТЕМ В УРБАНІЗОВАНОМУ СЕРЕДОВИЩІ
}

\begin{abstract}
Розкрито особливості формування зелених насаджень урбанізованих екосистем. Визначено видовий склад лісопаркових і паркових насаджень міста Львова та їх просторовий розподіл. Досліджено та узагальнено фітоценотичні особливості міських насаджень, зокрема, їх флористичну, вікову та екологічну структури, а також візуально-естетичні якості. Встановлено, що процеси урбанізації спричинили формування в лісопаркових і паркових насадженнях Львова нових рослинних асоціацій та появу у фітоценозах інтродукованих деревних видів. Встановлено, що видова різноманітність трав'яного вкриття лісопаркових і паркових зон безпосередньо залежить від топографічних, мікрокліматичних і грунтових умов місцевості, а також від видового складу деревного намету та його зімкнутості. Проаналізовано мікрокліматичні характеристики різних за видовим складом фітоценозів лісопаркових і паркових насаджень. 3'ясовано, що найбільш контрастними показниками мікрокліматичних особливостей лісопаркових і паркових фітоценозів, порівняно із показниками відкритого простору, характеризуються насадження із щільним наметом з перевагою у складі Carpinus betulus L., Quercus rubra Du Roi, Acer platanoides L., Acer pseudoplatanus L. та Quercus robur L. За особливостями мікрокліматичних показників у лісопаркових і паркових фітоценозах та відкритого простору виділено три групи рослинних асоціацій: за різницею температур і вологістю повітря - "холоднівологі", "помірні" та "теплі-сухі"; за вітровим режимом - "комфортні", "середнього комфорту" та "некомфортні"; за освітленістю надгрунтової поверхні: "темні", "середньої освітленості" та "світлі". Встановлено, що більш прогрітим є верхній шар грунтового покриву у фітоценозах "теплого-сухого" угруповання з перевагою у складі Pinus sylvestris L., Robinia pseudoacacia L., Betulla pendula Roth., Larix decidua Mill. та Acer negundo L. Визначено, що проективне трав'яне вкриття у рослинних асоціаціях, віднесених до груп "темних", або зовсім відсутнє, або не перевищує 5 \%, а у "світлих" фітоценозах становить $95-$ $100 \%$. Видове фіторізноманіття у "світлих" і "теплих-сухих" фітоценозах є вищим порівно із фітоценозами "середньої освітленості" i "помірних", а природне поновлення деревних видів у "темних" і "холодних-вологих" рослинних угрупованнях зазвичай відсутнє. Охарактеризовано групи рослинних асоціацій за шкалою естетичної цінності та санітарно-гігієнічними умовами згідно з виділеними кліматопами. Висвітлено значення відновлення фітоценотичної структури лісопаркових і паркових насаджень в оптимізації зелених зон урбанізованих екосистем.
\end{abstract}

Ключові слова: фіторізноманіття; біогеоценоз; термічний клімат; рослинна асоціація; озеленення; міські екосистеми.

Вступ. Урбанізоване середовище безпосередньо впливає на природні процеси розвитку зелених насаджень та на взаємовідносини різних компонентів садово-паркових екосистем. Завдяки комплексному підходу до озеленення міських територій формується єдина система міських і заміських насаджень, яка поєднує деревні, кущові та трав'яні види рослин. Раціональне розташування лісопаркових і паркових насаджень в межах комплексної зеленої зони міста $\epsilon$ визначальним для функціонування та розвитку урбанізованих територій $[3,4,6,7]$. Зелені зони міських екосистем, особливо лісопаркові та паркові насадження, сприяють оздоровленню урбоекосистеми, покращують мікроклімат міста та екологічний стан урбанізованого середовища $[2,4,8,9]$.

Дослідження природних процесів розвитку лісопаркових і паркових насаджень та взаємовідносин різних компонентів садово-паркових екосистем $є$ актуальними, що пов'язано із глобальним потеплінням та змінами клімату впродовж останніх десятиріч, внаслідок антропогенної діяльності.

Зважаючи на провідну роль рослинних угруповань та комплексних зелених зон міста у досягненні гармонійного балансу між урбанізованими та природними екосистемами, пізнання процесів розвитку лісопаркових і паркових насаджень в урбанізованому середовищі та пристосувань рослин до несприятливих антропоген-

\section{Інформація про авторів:}

Мельничук Назар Ярославович, аспірант, кафедра ландшафтної архітектури, садово-паркового господарства та урбоекології. Email: yarhenyk@gmail.com

Геник Ярослав В'ячеславович, д-р с.-г. наук, професор, завідувач кафедри ландшафтної архітектури, садово-паркового господарства та урбоекології. Email: уarhenyk@gmail.com; https://orcid.org/0000-0002-6079-6827

Мельничук Світлана Петрівна, ст. викладач, кафедра екологіï. Email: fotija@ukr.net

Паславський Михайло Михайлович, канд. техн. наук, пров. інженер, кафедра екології. Email: mykhaylo.paslavskyi@gmail.com; https://orcid.org/0000-0003-1635-4340

Цитування за ДСту: Мельничук Н. Я., Геник Я. В., Мельничук С. П., Паславський М. М. Природні процеси розвитку та взаємовідносини компонентів садово-паркових екосистем в урбанізованому середовищі. Науковий вісник НлтУ України. 2020, т. 30, № 1. C. 60-65.

Citation APA: Melnychuk, N. Ya., Henyk, Ya. V., Melnychuk, S. P., \& Paslavskyi, M. M. (2020). Natural processes of development and relationship between the components of garden and park ecosystems in the urban environment. Scientific Bulletin of UNFU, 30(1), 60-65. https://doi.org/10.36930/40300110 
них чинників, а також питання взаємовідносин компонентів садово-паркових екосистем є надзвичайно вагомими та актуальними задля формування екологічно ефективних і естетично привабливих міських зелених насаджень.

Аналіз літературних джсерел. Знання закономірностей розвитку природи - запорука правильного використання та відтворення її багатства [10]. Дослідження лісопаркових зон і зелених насаджень парків і скверів міста Львова здійснювали науковці різних науково-дослідних і освітніх установ, зокрема, співробітники Національного лісотехнічного університету України, Інституту екології Карпат НАН України та Львівського національного університету ім. Івана Франка.

Значний внесок у висвітлення процесів формування зелених зон Львова та видового складу і просторової структури лісопаркових і паркових насаджень міста зробили наукові напрацювання В. П. Кучерявого [6, 7, 8], М. М. Назарука [10]; I. М. Данилика, Я. В. Геника [3, 4]; Р. Б. Дудина, О. О. Кагала; В. М. Скробала; Н. А. Імшенецької, М. П. Курницької, О. І. Каспрук, С. Б. Марутяк, О. І. Дерех та ін. У їхніх численних наукових публікаціях висвітлено процеси розвитку міських насаджень, проаналізовано сучасний стан, видову, вікову та просторову структуру лісопаркових і паркових екосистем міста та запропоновано низку заходів із покращення санітарного стану і підвищення естетичної привабливості садово-паркових об'єктів комплексної зеленої зони Львова. Незважаючи на вагомість наукових напрацювань, аспекти оцінювання процесів розвитку та взаємовідносин різних компонентів садово-паркових екосистем у міському середовищі і надалі залишаються актуальними та потребують нових як наукових досліджень, так і практичних напрацювань.

Об'єкт дослідження - фітоценози паркових і лісопаркових насаджень міста Львова.

Предмет дослідження - природні процеси розвитку та взаємовідносини компонентів садово-паркових екосистем в урбанізованому середовищі.

Метою дослідження є з'ясування процесів розвитку садово-паркових насаджень в урбанізованому середовищі та оцінювання змін у фітоценотичному вкритті садово-паркових об'єктів Львова внаслідок впливу біотичних і абіотичних чинників на підставі аналізу результатів польових досліджень.

Основними завданнями дослідження є проведення аналізу особливостей формування фітоценотичного вкриття лісопаркових і паркових насаджень Львова, встановлення мікрокліматичних особливостей у різних фітоценозах урбанізованого середовища, а також виявлення взаємовідносин між різними компонентами екосистем у садово-паркових насадженнях міста.

Методи дослідження. Дослідження здійснено за апробованими методиками, з огляду на завдання системного підходу із вивчення процесів природного розвитку садово-паркових насаджень в урбанізованих екосистемах. У процесі наукового пошуку, аналізу та натурного обстеження садово-паркових об'єктів Львова використано історико-географічний, порівняльний, маршрутнорекогносцирувальний та статистичний методи. Видовий склад рослинності лісопаркових і паркових насаджень встановлено відповідно до вітчизняної номенклатури назв $[5,11]$.

Оскільки озеленення Львова здійснювали в міру його розбудови, підібрати на стаціонарних пунктах дос- лідження у лісопаркових і паркових насадженнях міста однакові за складом, віком та структурою угруповання фітоценозів виявилось практично неможливим. Головну увагу під час проведення досліджень зосереджували на підбиранні найтиповіших для умов Львова садовопаркових рослинних угруповань.

Дослідження процесів розвитку садово-паркових насаджень Львова та формування фітоценотичного вкриття лісопарків і парків міста проведено впродовж 20152019 рр. Для встановлення взаємовідносин компонентів садово-паркових екосистем в урбанізованому середовищі підібрали типові рослинні угруповання (ділянки площею $150 \mathrm{~m}^{2}$ ), які характеризують садово-паркові насадження міста: парк "Високий Замок" (350-380-413 м н.р.м.; площа 36,2 га), парк ім. Івана Франка (270-280 м н.р.м.; площа 11,3 га), Стрийський парк (320 м н.р.м.; площа 56 га), парк "Снопківський" (330-350 м н.р.м.; площа 35,7 га), парк "Залізна вода" (330-350 м н.р.м.; площа 19,5 га), парк "Личаківський" (360-380 м н.р.м.; площа 12,4 га), парк "Шевченківський гай" (340-375 м н.р.м.; площа 36,5 га), лісопарк "Погулянка" (320-379 м н.р.м.; площа 100,3 га) та лісопарк "Зубра" (350-380 м н.р.м.; площа 97,9 га).

Вивчення видового складу рослинних угруповань здійснювали методом видових майданчиків (1 м²). Мікрокліматичні показники у фітоценозах садово-паркових об'єктів фіксували щогодини, починаючи з 9.00 до 16.00 год на трьох пунктах: пункт № 1 розміщено під наметом дерев - насадження; пункт № 2 на відстані 4050 м від пункту № 1 - трав'яне вкриття; пункт № 3 покриття доріжково-стежкової мережі (м'яке вкриття із стабілізуючими домішками, тротуарна плитка, асфальт та ін.).

Результати дослідження. Розвиток Львова супроводжувався формуванням комплексної зеленої зони та послідовній трансформації фітоценотичного вкриття внаслідок дії природних і антропогенних чинників. У оптимізації урбанізованого середовища важливе місце належить зеленим насадженням, особливо лісопарковим і парковим насадженням, які окрім естетичної та декоративної функцій, створюють на території міста сприятливі мікрокліматичні та санітарно-гігієнічні умови, а також сприяють функціональній організації урбанізованої території та оздоровленню міського середовища $[1,6,8]$.

Фітоценоточне вкриття на дослідних ділянках у паркових i лісопаркових насадженнях міста характеризується значним різноманіттям (табл. 1). Фітоценози досліджуваних садово-паркових об'єктів характеризуються певним видовим складом та будовою, які насамперед залежать від географічних, топографічних, мікрокліматичних і грунтових умов, а також типу рослинного вкриття. Видова різноманітність трав'яного вкриття безпосередньо залежить від видового складу деревного намету та його зімкнутості (див. табл. 1).

За результатами аналізу вікової структури досліджуваних насаджень парків та лісопарків Львова з'ясовано, що більшість деревних видів $є$ у віці 60-100 років (за винятком невеликої кількості у парках і лісопарках дерев-довгожителів). Так, наприклад, соснові насадження (з перевагою Pinus nigra Arn.) формуються здебільшого деревами 70-80 річного віку; грабові насадження представлені різновіковими примірниками, з яких найбільша чисельність припадає на 50-60 років. У пересічному 
рельєфі місцевості, в районі ярів та балок, трапляється значна кількість примірників Quercus robur L. який разом 3 Fraxinus excelsior L., Acer platanoides L. та Acer pseudoplatanus L. виходять у перший ярус насадження та досягають віку 80-90 років.

Табл. 1. Фітоценотичне вкриття садово-паркових об'єктів міста Львова

\begin{tabular}{|c|c|c|c|c|}
\hline $\begin{array}{l}\text { № } \\
\text { 3/П }\end{array}$ & Назва об'єкта & Дерева & Кущі & Трави \\
\hline 1 & $\begin{array}{c}\text { Парк "Високий } \\
\text { Замок" }\end{array}$ & $\begin{array}{c}\text { Quercus robur } \mathrm{L} ., \\
\text { Robinia pseudoacacia } \mathrm{L} ., \\
\text { Acer pseudoplatanus } \mathrm{L} ., \\
\text { Larix decidua } \text { Mill., } \\
\text { Betulla pendula } \text { Roth., } \\
\text { Salix caprea } \mathrm{L} ., \\
\text { Salix alba } \mathrm{L} . \\
\text { A }=60-100 \text { років } \mathrm{H}=12-20 \mathrm{M}\end{array}$ & $\begin{array}{c}\text { Sambucus nigra } \mathrm{L} ., \\
\text { Deutzia scabra Thunb. } \\
\mathrm{H}=1,5-2,0 \mathrm{M}\end{array}$ & $\begin{array}{c}\text { Панівні види у "вікнах" } \\
\text { деревного намету: } \\
\text { Poa pratensis L., } \\
\text { Trifolium pratense L., } \\
\text { Dryopteris filix-mas }(\mathrm{L} .) \text { Schott, } \\
\text { Urtica dioica } \mathrm{L} ., \\
\text { Stellaria nemorum L., } \\
\text { Sedum telephium } \mathrm{L} . \mathrm{H}=6 \mathrm{~cm}\end{array}$ \\
\hline 2 & Парк ім. І. Франка & $\begin{array}{c}\text { Acer pseudoplatanus L., } \\
\text { Acer platanoides L., } \\
\text { Platanus occidentalis } \mathrm{L} ., \\
\text { Pyrus communis } \mathrm{L} . \\
\mathrm{A}=80-100 \text { років } \mathrm{H}=14-24 \mathrm{M}\end{array}$ & $\begin{array}{l}\text { Rhamnus cathartica } \mathrm{L} ., \\
\text { Cornus mas L., } \\
\text { Frangula alnus Mill., Phi- } \\
\text { ladelphus coronarius } \mathrm{L} . \\
\mathrm{H}=1,0-1,5 \mathrm{M} \\
\end{array}$ & $\begin{array}{c}\text { Звичайний садово-парковий газон } 3 \\
\text { панівними видами: Plantago ma- } \\
\text { jor L., Bromus mollis L., } \\
\text { Urtica dioica L. } \\
\text { H = } 6 \text { cм }\end{array}$ \\
\hline 3 & Стрийський парк & $\begin{array}{c}\text { Quercus robur } \mathrm{L} ., \\
\text { Larix decidua } \text { Mill., } \\
\text { Robinia pseudoacacia } \mathrm{L} ., \\
\text { Carpinus betulus } \mathrm{L} ., \\
\text { Pinus nigra } \text { Arn., } \\
\text { Pinus sylvestris L., } \\
\text { Cercidiphyllum japonicum } \mathrm{S} \text {. et } \mathrm{Z} ., \\
\text { Acer platanoides } \mathrm{L} ., \\
\text { Tilia cordata } \text { Mill. } \\
\mathrm{A}=70-80 \text { років } \mathrm{H}=18-22 \mathrm{м} \\
\end{array}$ & $\begin{array}{c}\text { Sambucus nigra } \mathrm{L} ., \\
\text { Deutzia scabra Thunb. } \\
\mathrm{H}=1,5-2,0 \mathrm{M}\end{array}$ & $\begin{array}{c}\text { Звичайний садово-парковий газон } 3 \\
\text { панівними видами: } \\
\text { Elytrigia repens (L.) Desv., } \\
\text { Poa pratensis L., } \\
\text { Plantago major L. } \\
\text { H = } 4 \text { cм }\end{array}$ \\
\hline 4 & $\begin{array}{c}\text { Парк "Снопківсь- } \\
\text { кий" }\end{array}$ & $\begin{array}{l}\text { Fagus sylvatica } \mathrm{L} ., \\
\text { Acer platanoides } \mathrm{L} ., \\
\text { Larix decidua } \text { Mill., } \\
\text { Robinia pseudoacacia } \mathrm{L} ., \\
\text { Tilia cordata } \text { Mill. } \\
\mathrm{A}=60-80 \text { років; } \mathrm{H}=10-14 \text { м }\end{array}$ & $\begin{array}{c}\text { Sambucus nigra } \mathrm{L} ., \\
\text { Swida sanguinea }(\mathrm{L} .) \text { Opiz } \\
\mathrm{H}=1,0-1,5 \mathrm{M}\end{array}$ & $\begin{array}{c}\text { Звичайний садово-парковий } \\
\text { газон } 3 \text { панівними видами: } \\
\text { Aegopodium podagraria L., } \\
\text { Salvia glutinosa } \mathrm{L} ., \\
\text { Urtica dioica } \mathrm{L} ., \\
\text { Poa nemoralis } \mathrm{L} ., \\
\text { Impatiens parviflora } \text { DC. } \mathrm{H}=6 \mathrm{~cm} \\
\end{array}$ \\
\hline 5 & Парк "Залізна вода" & $\begin{array}{c}\text { Acer platanoides } \mathrm{L} ., \\
\text { Aesculus hippocastanum } \mathrm{L} . \\
\text { Robinia pseudoacacia } \mathrm{L} . \\
\text { Tilia cordata } \text { Mill. } \\
\mathrm{A}=70-80 \text { років } \mathrm{H}=18-22 \mathrm{м}\end{array}$ & $\begin{array}{c}\text { Frangula alnus Mill., Sam- } \\
\text { bucus nigra L., } \\
\text { Deutzia scabra Thunb. } \\
\mathrm{H}=1,5-2,0 \mathrm{M}\end{array}$ & $\begin{array}{c}\text { Звичайний садово-парковий газон } 3 \\
\text { панівними видами: Festuca rubra L., } \\
\text { Lolium perenne L., Poa annua L., } \\
\text { Impatiens balsamina } \mathrm{L} ., \\
\text { Trifolium pratense L., } \\
\text { Urtica dioica } \mathrm{L} . \mathrm{H}=6 \mathrm{~cm} \\
\end{array}$ \\
\hline 6 & $\begin{array}{c}\text { Парк "Личаківсь- } \\
\text { кий" }\end{array}$ & $\begin{array}{c}\text { Fagus sylvatica } \mathrm{L}, \\
\text { Pinus nigra Arn., } \\
\text { Betulla pendula } \text { Roth., } \\
\text { Aesculus hippocastanum } \mathrm{L} ., \\
\text { Acer pseudoplatanus } \mathrm{L} . \\
\mathrm{A}=80-90 \text { років; } \mathrm{H}=20-25 \mathrm{м}\end{array}$ & $\begin{array}{l}\text { Syringa vulgaris } \mathrm{L} ., \\
\text { Spiraea salicifolia } \mathrm{L} ., \text { Phi- } \\
\text { ladelphus coronarius } \mathrm{L} ., \\
\text { Rubus sp. } \mathrm{L} ., \\
\mathrm{H}=1,5-2,0 \mathrm{M}\end{array}$ & $\begin{array}{c}\text { Звичайний садово-парковий } \\
\text { газон } 3 \text { панівними видами: } \\
\text { Anemone nemorosa L., } \\
\text { Corydalis solida (L.) Clairv., } \\
\text { Dentaria glandulosa Waldst.et Kit., } \\
\text { Glechoma hederacea L., } \\
\text { Impatiens parviflora } \text { DC. } \mathrm{H}=6 \text { cм }\end{array}$ \\
\hline 7 & $\begin{array}{c}\text { Парк "Шевченківсь- } \\
\text { кий гай" }\end{array}$ & $\begin{array}{l}\text { Acer pseudoplatanus } \mathrm{L} ., \\
\text { Acer platanoides } \mathrm{L} ., \\
\text { Tilia cordata } \text { Mill., } \\
\text { Betulla pendula } \text { Roth., } \\
\text { Carpinus betulus } \mathrm{L} ., \\
\text { Robinia pseudoacacia } \mathrm{L} ., \\
\text { Salix alba } \mathrm{L} . \\
\mathrm{A}=50-60 \text { років } ; \mathrm{H}=14-20 \mathrm{~m} ; \\
\end{array}$ & $\begin{array}{c}\text { Sambucus nigra } \mathrm{L} ., \\
\text { Swida sanguinea }(\mathrm{L} .) \text { Opiz } \\
\mathrm{H}=1,0-1,5 \mathrm{M}\end{array}$ & $\begin{array}{c}\text { Панівні види у "вікнах" деревного } \\
\text { намету: } \\
\text { Bromus mollis L., } \\
\text { Urtica dioica L. } \\
\text { H = } 6 \mathrm{~cm}\end{array}$ \\
\hline 8 & $\begin{array}{c}\text { Лісопарк } \\
\text { "Погулянка" }\end{array}$ & $\begin{array}{c}\text { Fagus sylvatica } \mathrm{L} ., \\
\text { Quercus robur L., Carpinus betulus L., } \\
\text { Larix decidua } \text { Mill., } \\
\text { Acer pseudoplatanus } \mathrm{L} ., \\
\text { Robinia pseudoacacia } \mathrm{L} ., \text { Betulla pen- } \\
\quad \text { dula } \text { Roth. } \\
\text { A }=80-100 \text { років; } \mathrm{H}=12-30 \mathrm{M}\end{array}$ & $\begin{array}{c}\text { Sambucus nigra } \mathrm{L} ., \\
\text { Deutzia scabra Thunb. } \\
\mathrm{H}=1,5-2,0 \mathrm{M}\end{array}$ & $\begin{array}{l}\text { Панівні види у "вікнах" деревного } \\
\text { намету: } \\
\text { Dryopteris filix-mas (L.) Schott, } \\
\text { Urtica dioica } \mathrm{L} ., \\
\text { Stellaria nemorum L., } \\
\text { Sedum telephium L., } \\
\text { Aegopodium padagraria } \text { L. } \mathrm{H}=6 \mathrm{~cm}\end{array}$ \\
\hline 9 & Лісопарк "Зубра" & \begin{tabular}{|} 
Quercus robur L., Carpinus betulus L., \\
Larix decidua Mill., \\
Acer pseudoplatanus L., \\
Robinia pseudoacacia L., Fraxinus ex- \\
celsior L., Betulla pendula Roth. \\
A = $60-80$ років, $\mathrm{H}=12-20 \mathrm{M}$
\end{tabular} & $\begin{array}{c}\text { Sambucus nigra L., } \\
\text { Deutzia scabra Thunb. } \\
\mathrm{H}=1,5-2,0 \mathrm{M}\end{array}$ & $\begin{array}{c}\text { Панівні види у "вікнах" деревного } \\
\text { намету: Urtica diolca L., } \\
\text { Stellaria nemorum L., } \\
\text { Sedum telephium L., } \\
\text { Aegopodium padagraria L. } \\
\text { H = } 6 \text { cм }\end{array}$ \\
\hline
\end{tabular}


Процеси урбанізації спричинили появу в паркових i лісопаркових насадженнях Львова нових рослинних асоціацій, а у складі деревного ярусу присутні такі інтродуковані деревні види, як Aesculus hippocastanum L., Acer negundo L., Platanus occidentalis L. та Cercidiphyllum japonicum $\mathrm{S}$. et $\mathrm{Z}$.

Підлісок паркових і лісопаркових насаджень формують такі деревні види як: Sambucus nigra L., Deutzia scabra Thunb., Rhamnus cathartica L., Cornus mas L., Frangula alnus Mill., Philadelphus coronarius L., Swida sanguinea (L.) Opiz, Syringa vulgaris L., Spiraea salicifolia L. У трав'яному вкритті садово-паркових об'єктів багато лісових і лучних видів із значним включенням синантропних рослин.

Аналіз результатів проведених досліджень показав, що мікрокліматичні особливості лісопаркових і паркових фітоценозів на досліджуваних ділянках значно різняться. Деревний намет насаджень формує специфічні термічні кліматопи залежно від зімкнутості крон і видового складу деревних рослин у насадженні (табл. 2).

Табл. 2. Мікрокліматичні показники урбанізованих фітоценозів і відкритих просторів (червень-липень 2017-2019 рр.)

\begin{tabular}{|c|c|c|c|c|}
\hline \multirow{2}{*}{ Едифікатор фітоценозу } & \multicolumn{3}{|c|}{ Різниця мікрокліматичних показників, \% до відкритого простору } \\
\cline { 2 - 5 } & Температура & Відносна вологість & Швидкість вітру & Освітленість \\
\hline Граб звичайний & 3,83 & 14,51 & 0,18 & 2,00 \\
\hline Дуб звичайний & 3,02 & 12,05 & 0,13 & 3,40 \\
\hline Дуб червоний & 3,91 & 15,07 & 0,19 & 2,20 \\
\hline Дуб звичайний із модриною & 2,55 & 10,04 & 0,11 & 4,30 \\
\hline Клен гостролистий & 4,04 & 16,59 & 0,18 & 2,10 \\
\hline Модрина європейська & 2,06 & 7,21 & 0,15 & 5,20 \\
\hline Сосна звичайна & 1,67 & 6,64 & 0,10 & 4,20 \\
\hline Береза повисла & 2,05 & 6,77 & 0,35 & 6,20 \\
\hline Робінія звичайна & 2,28 & 7,28 & 0,32 & 5,80 \\
\hline Клен ясенелистий & 2,33 & 7,49 & 0,27 & 5,10 \\
\hline Клен-явір & 3,62 & 14,13 & 0,18 & 2,80 \\
\hline Ясен звичайний & 2,46 & 11,07 & 0,18 & 4,70 \\
\hline Ясен зелений & 2,67 & 11,24 & 0,12 & 4,30 \\
\hline
\end{tabular}

Найбільш контрастними показниками мікрокліматичних особливостей, порівняно із показниками відкритого простору, характеризуються насадження із щільним наметом граба звичайного, клена гостролистого, дуба червоного, клена-явора і дуба звичайного. Насадження, в яких дерева-едифікатори утворюють ажурну крону (береза повисла, біла акація, клен гостролистий, ясен звичайний, ясен зелений, сосна звичайна та модрина європейська), характеризуються менш контрастними мікрокліматичними показниками порівняно із показниками відкритого простору.

Виконані дослідження за рівнем різниць температур i вологості повітря у рослинних угрупованнях та відкритого простору дали змогу виділили три групи рослинних асоціацій:

- "холодні-вологі" (з різницею температур відкритого і закритого просторів $3,1-4,1{ }^{\circ} \mathrm{C}$ та різницею відносної вологості повітря 14,0-16,6 \%) - насадження із граба звичайного, дуба червоного, клена гостролистого та клена-явора;

- "помірні" (з різницею температур відкритого і закритого просторів $2,4-3,1{ }^{\circ} \mathrm{C}$ та різницею відносної вологості повітря 10,0-14,0 \%) - насадження із дуба звичайного, дуба звичайного з модриною європейською, ясена звичайного і ясена зеленого;

- "теплі-сухі" (з різницею температур відкритого і закритого просторів 1,6-2,4 ${ }^{\circ} \mathrm{C}$ та різницею відносної вологості повітря 6,6-10,0 \%) - насадження із сосни звичайної, білої акації, берези повислої, модрини європейської, клена ясенелистого.

За рівнем вітрового режиму рослинні асоціації пар-

кових і лісопаркових насаджень згруповано так:

• "комфортні" (відношення швидкостей вітру в закритому просторі фітоценозу та у відкритому просторі становить $0,10-0,17 \%$ ) - насадження із сосни звичайної, дуба звичайного із модриною, дуба звичайного, модрини європейської та ясена зеленого;

- "середнього комфорту" (відношення швидкостей вітру 0,18$0,25 \%$ - насадження із граба звичайного, ясена звичайного, клена гостролистого та клена-явора;

• "некомфортні" (відношення швидкостей вітру 0,26$0,35 \%$ - насадження із клена ясенелистого, білої акації та берези повислої.
За рівнем освітленості надгрунтової поверхні рослинні асоціації насаджень об'єднано в такі групи:

- "темні" (відношення освітленості піднаметового простору та відкритої місцевості становить 2,0-3,4 \%) - насадження із граба звичайного, дуба червоного, клена гостролистого та клена-явора;

• "середньої освітленості" (відношення освітленості 3,4$4,8 \%$ - насадження із дуба звичайного, дуба звичайного 3 модриною, сосни звичайної, ясеня зеленого та ясеня звичайного;

• "світлі" (відношення освітленості 4,8-6,2 \%) - насадження із клена ясенелистого, модрини європейської, білої акації та берези повислої.

Мікрокліматичні показники досить широко корелюють із показниками розвитку трав'яного вкриття та із грунтовим кліматом: більш прогрітим виявився верхній шар грунтового покриву (глибина до 5 см) у насадженнях сосни звичайної, акації білої, берези повислої, модрини європейської та клена ясенелистого, тобто у фітоценозах "теплого-сухого" угруповання (табл. 3).

y "темних" i "холодних-вологих" насадженнях із граба звичайного, дуба червоного, клена гостролистого та клена-явора трав'яне вкриття або зовсім відсутнє, або його проективне покриття не перевищує $5 \%$ (насадження клена-явора). У фітоценозах "середньої освітленості" i "помірних" проективне трав'яне вкриття коливається в межах 14-85 \%. У "світлих" і "теплих-сухих" фітоценозах проективне трав'яне вкриття становить 95$100 \%$ (окрім модринового насадження - проективне покриття $64 \%$ ).

Видове фіторізноманіття у "світлих" і "теплих-сухих" фітоценозах є більшим порівняно із фітоценозами "середньої освітленості" і "помірних". Природне поновлення деревних видів у "темних" i "холодних-вологих" повністю відсутнє, у фітоценозах "середньої освітленості" і "помірних" - задовільне або ж погане, а у "світлих" i "теплих-сухих" рослинних угрупованнях - погане або ж слабке. 
Табл. 3. Стан надгрунтового вкриття в урбанізованих фітоценозах різного ступеня освітленості

\begin{tabular}{|c|c|c|c|c|c|c|}
\hline \multirow{4}{*}{ Едифікатор фітоценозу } & \multirow{4}{*}{$\begin{array}{c}\text { Група } \\
\text { освітленості }\end{array}$} & \multicolumn{2}{|c|}{ Трав'яне вкриття } & \multicolumn{3}{|c|}{ Природне поновлення деревних видів } \\
\hline & & \multirow{3}{*}{$\begin{array}{c}\text { проективне } \\
\text { вкриття }\end{array}$} & \multirow{3}{*}{$\begin{array}{c}\text { кількість } \\
\text { видів }\end{array}$} & перевах & сту (роки) & \multirow{3}{*}{$\begin{array}{c}\text { оцінка понов- } \\
\text { лення за Нес- } \\
\text { теровим }\end{array}$} \\
\hline & & & & $1-5$ & $6-10$ & \\
\hline & & & & \multicolumn{2}{|c|}{ кількість сприятливих сходів, тис. шт/га } & \\
\hline Граб звичайний & темні & 0 & - & 0 & 0 & - \\
\hline Клен гостролистий & темні & 0 & - & 0 & 0 & - \\
\hline Дуб червоний & темні & 0 & - & 0 & 0 & - \\
\hline Клен-явір & темні & 5 & 4 & 0 & 0 & - \\
\hline Дуб звичайний & сер. освітл. & 14 & 14 & 3,0 & 3,0 & погане \\
\hline Дуб звичайний із модриною & сер. освітл. & 45 & 16 & 5,0 & 3,2 & задовільне \\
\hline Сосна звичайна & сер. освітл. & 29 & 6 & 3,0 & 3,0 & погане \\
\hline Ясен зелений & сер. освітл. & 78 & 29 & 5,1 & 3,0 & задовільне \\
\hline Ясен звичайний & сер. освітл. & 85 & 27 & 5,1 & 3,0 & задовільне \\
\hline Клен ясенелистий & світлі & 95 & 14 & 3,2 & 1,0 & слабке \\
\hline Модрина європейська & світлі & 64 & 12 & 3,0 & 3,0 & погане \\
\hline Біла акація & світлі & 100 & 39 & 3,0 & 3,0 & погане \\
\hline Береза повисла & світлі & 100 & 41 & 3,0 & 3,0 & погане \\
\hline
\end{tabular}

Використавши запропоновані В. П. Кучерявим [6, 7] шкали естетичної цінності рослинних угруповань (таксаційно-фітоценотичну та емоційну шкали), можна встановити, що до I класу належать "світлі" і "теплі-сухі" фітоценози, до II класу - фітоценози "середньої освітленості" і "помірні", та до III класу - "темні" та "холодні-вологі" фітоценози.

Для досліджуваних рослинних асоціацій у зелених насадженнях міста санітарно-гігієнічні умови фітоценозів отримали оцінку (за радіаційно-еквівалентно-ефективною температурою (РЕET), яка характеризує клімато-лікувальні ресурси місцевості та шкалою тепловідчуття В. І. Русанова - межі РЕЕТ для роздягненої 20,3$24,7^{\circ} \mathrm{C}$ та одягненої $19,7-23,6^{\circ} \mathrm{C}$ людини): "тепло" "світлі" і "теплі-сухі" фітоценози та "комфортно" - "середньої освітленості" та "помірні" фітоценози.

Висновки. Урбанізаційні процеси безпосередньо впливають на формування лісопаркових і паркових насаджень та супроводжуються зміною видового складу і структури природної рослинності зелених зон. У фітоценозах лісопаркових i паркових насаджень відбувається заміщення головної едифікаторної деревної породи на субедифікаторні деревні види та збільшення частки в трав'яному вкритті синантропних видів рослин.

Фітоценоточне вкриття лісопаркових і паркових насаджень Львова насамперед залежить від географічних, топографічних, мікрокліматичних і грунтових умов місцевості та характеризується значною біорізноманітністю. Видова різноманітність трав'яного вкриття безпосередньо залежить від видового складу деревного намету та його зімкнутості.

Деревний намет лісопаркових і паркових насаджень формує специфічні термічні кліматопи залежно від видового складу деревних рослин у фітоценозі та зімкнутості намету. Найбільш контрастними показниками мікрокліматичних особливостей фітоценозів, порівняно із показниками відкритого простору, характеризуються насадження із щільним наметом граба звичайного, клена гостролистого, дуба червоного, клена-явора і дуба звичайного.

За особливостями порівняння мікрокліматичних показників у фітоценозах і відкритого простору можна виділити три групи рослинних асоціацій: за різницею температур і вологістю повітря - "холодні-вологі", "помірні" та "теплі-сухі"; за вітровим режимом - "комфортні", "середнього комфорту" та "некомфортні"; за освітленістю надгрунтової поверхні - "темні", "середньої освітленості" та "світлі".

у "темних" і "холодних-вологих" фітоценозах (насадження із перевагою у складі граба звичайного, дуба червоного, клена гостролистого та клена-явора) трав'яне вкриття або зовсім відсутнє, або його проективне покриття не перевищує $5 \%$. У фітоценозах "середньої освітленості" і "помірних" (насадження із перевагою у складі дуба звичайного, сосни звичайної, ясена звичайного та ясена зеленого) проективне трав'яне вкриття коливається в межах 14-85\%. У "світлих" і "теплих-сухих" фітоценозах (насадження із перевагою у складі клена ясенелистого, білої акації та берези повислої) проективне трав'яне вкриття становить 95-100 \%.

Видове фіторізноманіття у "світлих" і "теплих-сухих" фітоценозах є більшим порівняно із фітоценозами "середньої освітленості" і "помірних", а природне поновлення деревних видів у "темних" і "холодних-вологих" рослинних угрупованнях $\epsilon$ відсутнім.

За шкалою естетичної цінності рослинних угруповань "світлі" і "теплі-сухі" фітоценози належать до I класу, фітоценози "середньої освітленості" і "помірні" до II класу, "темні" та "холодні-вологі" фітоценози - до III класу.

Аналіз особливостей природно-мікрокліматичних умов кожної ділянки, специфіки іiї розташування, функціонального та змістовного призначення сприятиме умілому використанню елементів озеленення, які б створювали комфортний фітоклімат міського середовища та характеризувались високою естетичною цінністю і декоративною привабливістю.

Для оптимізації фітоценотичної структури лісопаркових і паркових насаджень Львова необхідно і надалі розробляти науково обгрунтовані заходи із удосконалення планування ландшафтно-просторової організації зелених зон, збагачення асортименту декоративних рослин, підвищення естетичної цінності і рекреаційної привабливості насаджень та мінімізації негативних процесів антропогенного впливу на зелені екосистеми міста.

\section{References}

1. Boiko, T. O., Dementieva, O. I., \& Kotovska, Yu. S. (2019). Assessment of biological and ecological properties of woody lianasin the conditions of the city of Kherson. Scientific Bulletin of UNFU, 29(5), 31-35. https://doi.org/10.15421/40290506 
2. Derekh, O. I. (2013). Termoradiatsiyni kharakterystyky klimatu ta yikh ekolohichnyy zv'yazok iz fitotsenozom. Scientific Bulletin of UNFU, 23(2), 141-145. [In Ukrainian].

3. Henyk, Ya. V. (2013). Chynnyky transformatsiinykh protsesiv u nasadzhenniakh kompleksnykh zelenykh zon urbanizovanykh ekosystem. Scientific Bulletin of UNFU, 23(2), 113-118. [In Ukrainian].

4. Henyk, Ya. V., Dudyn, R. B., Dyda, A. P., Marutyak, S. B., \& Kaspruk, O. I. (2017). Transformatsiyni protsesy v lisoparkovykh i parkovykh nasadzhennyakh urbanizovanykh ekost'stem Zakhodu Ukrayiny. Scientific Bulletin of UNFU, 27(10), 9-15. https://doi.org/10.15421/40271001

5. Kohno, M. A. (2001). Catalog of of dendroflora of of Ukraine. Kyiv: Phitosotsiotsentr, 448 p. [In Ukrainian].

6. Kucheriavyi, V. P. (1981). Green area of the city. Kyev: Naukova dumka, 248 p. [In Russian].
7. Kucheriavyi, V. P. (2008). Lviv Gardens and Parks. Lviv: Vyd-vo "Svit", 360 p. [In Ukrainian].

8. Kucheriavyi, V. P. (2019). Landscaping of settlements. Lviv: Novyy svit, 620 p. [In Ukrainian].

9. Melnychuk, S. P. (2003). Mikroklimat riznykh typiv pidstylayuchoyi poverkhni u m. Lvovi. Problemy urboekolohiyi, urbolandshaftoznavstva i fitomelioratsi: materialy mizhnarodnoyi konferentsiyi. Lviv: UkrDLTU, 7 p. [In Ukrainian].

10. Nazaruk, M., Senchyna, B., \& Sholok, I. (2016). Conservation of phytodivesity as a way to optimize social-ecosystem of Lviv. (Ser.: Geography). Visnyk of the Lviv University, 1, 179-183. [In Ukrainian].

11. Zaiachuk, V. Ya. (2008). Dendrology. Lviv: Apriori, 656 p. [In Ukrainian].

N. Ya. Melnychuk, Ya. V. Henyk, S. P. Melnychuk, M. M. Paslavskyi

Ukrainian National Forestry University, Lviv, Ukraine

\section{NATURAL PROCESSES OF DEVELOPMENT AND RELATIONSHIP BETWEEN THE COMPONENTS OF GARDEN AND PARK ECOSYSTEMS IN THE URBAN ENVIRONMENT}

The peculiarities of the development of green belts within the urban ecosystems have been revealed. Additionally, the study unveiled the species' and spatial composition of the forest and park plantations at Lviv. The study also investigated and generalized the phytocenotic features of urban plantations, as well as their visual and aesthetic qualities. Furthermore, the results uncovered that urbanization processes led to the formation of new plant associations in the forest and park plantations of Lviv and the emergence introduced tree species within phytocoenoses. Additionally, there is a direct relation between the species diversity of grassland coverage of forests and parks that correlates with topographic, microclimatic, and soil conditions of the terrain, as well as species composition of tree community and its canopy. Moreover, the study focused on the analysis of microclimatic characteristics of the forest park and park plantations' phytocoenoses. Quite interestingly, the brightest microclimatic specifics of the forest park and park phytocoenoses are present in the tree communities with the superiority of Carpinus betulus L., Acer hlatanoides L., Quercus rubra Du Roi, Acer pseudoplatanus L. and Quercus robur L. Three groups of plant associations were distinguished, according to the peculiarities of the microclimatic indicators of the forest park and park phytocoenoses and open space: temperature and humidity differences "cold-humid," "moderate" and "warm-dry"; wind mode - "comfortable," "average comfort," "uncomfortable"; illumination of the soil surface - "dark," "medium light," and "light". Even more, phytocoenoses of the "warm-dry" group is warmer where Pinus sylvestris L., Robinia pseudoacacia L., Betulla pendula Roth., Larix decidua Mill. and Acer negundo L. are dominant. Projective grass coverage is completely absent or does not exceed $5 \%$ among the "dark" plant associations and 95-100 \% in "light" phytocoenoses. According to the distinguished climatopes, the plant associations are characterized on the scale of the aesthetic value as well as sanitary and hygiene conditions. Finally, the article highlights the importance of restoration of the phytocenotic structure of forest parks and park plantations in the optimization of green areas within urban ecosystems.

Keywords: phytodiversity; biogeocoenosis; thermal climatope; plant association; landscaping; urban ecosystems. 